\title{
Self-Assembling Molecular Trees Containing Octa-p-phenylene; From Nanocrystals to Nanocapsules
}

\section{Supporting Informations}

\section{Experimental section}

\section{Materials}

Chlorotrimethylsilane (98\%), tetrakis(triphenylphosphine)palladium(0) (99\%), pentaerythritol (98\%), n-butyllithium (1.6 M solution in $n$-hexane), 4,4'dibromobiphenyl (98\%), 4-bromo-4'-hydroxybiphenyl (97\%), borane-THF comeplx (1.0 M solution in THF), boron tribromide (1.0 M solution in dichloromethane), 18crown-6 (99\%), potassium iodide (99\%), 1,4-benzoquinone (98\%), bromine (99\%), triisopropyl borate (98+\%), iodomethane (99\%), iodine monochloride (1.0M solutuion in dichloromethane), 4-bromoanisole (99\%), 4-bromobiphenyl (98\%), (all from Aldrich) and the conventional reagents were used as received. 4-Trimethylsilyl-biphenyl-4'boronic acid, 1,4-dibromo-2,5-dimethoxybenzene(3a), 4-diphenyl boronic acid , and dendritic oligoether coils $\left(\mathbf{R}_{\mathbf{1}}\right.$ and $\left.\mathbf{R}_{\mathbf{2}}\right)$ were prepared according to the similar procedures described previously. ${ }^{9,10}$

Synthesis of 1-bromo-4-(trimethoxysilyl)-2,5-dimethoxybenzene (3b). To a suspension of $5 \mathrm{a}(30 \mathrm{~g}, 0.10 \mathrm{~mol})$ in ether $(250 \mathrm{ml})$ at $-78{ }^{\circ} \mathrm{C}$, was dropped $1.6 \mathrm{M}$ solution of $n$-BuLi in hexane $(70 \mathrm{ml})$ with vigorous stirring under nitrogen. After $2 \mathrm{hr}$, trimethylsilane (30 ml, $0.25 \mathrm{~mol}$ ) was added dropwise to the mixture, allowed to warm to room temperature and then stirred over $12 \mathrm{hrs}$ under nitrogen. To the reaction mixture, 
was added water $(300 \mathrm{ml})$. The layers were separated, the aqueous layer was washed twice with ether $(200 \mathrm{ml})$ and the combined organic layers were combined and then dried over anhydrous $\mathrm{MgSO}_{4}$, and filtered. The solvent was removed in a rotary evaporator, and the crude products was purified by column chromatography (silica gel, n-hexane) to yield $23 \mathrm{~g}$ ( 80\%) of a white crystal : mp ${ }^{\circ} \mathrm{C} ;{ }^{1} \mathrm{H}-\mathrm{NMR}$ (250 MHz, $\mathrm{CDCl}_{3}$, א, ppm ) 0.30 (s, 9H, $\left.\left(\mathrm{CH}_{3}\right)_{3} \mathrm{Si}\right)$, 3,80-3.90 (2s, 6H, OCH $), 6.96$ (s, 1H, m to Br), 7.06 (s, $1 \mathrm{H}, \mathrm{o}$ to $\mathrm{Br})$

Synthesis of 2,5,4'-trimethoxy-4-trimethylsilyl-biphenyl (4a). Compound 3b (16.7 g, $57.8 \mathrm{mmol}$ ) and 4-methoxybenzoboronic acid (8.8 g, $57.8 \mathrm{mmol})$ were dissolved in degassed DME $(150 \mathrm{ml})$. Degassed $2 \mathrm{M}$ aqueous $\mathrm{Na}_{2} \mathrm{CO}_{3}(150 \mathrm{ml})$ was added to the solution and then tetrakis(triphenylphosphine)palladium(0) (334 mg, $0.29 \mathrm{mmol}$ ) was added. The mixture was refluxed for 24 hrs with vigorous stirring under nitrogen. Cooled to room temperature, the layers were separated, the aqueous layer was washed twice with ethyl acetate. The combined organic layer was dried over anhydrous $\mathrm{MgSO}_{4}$ and filtered. The solvent was removed in a rotary evaporator, and the crude products was purified by column chromatography (silica gel, $\mathrm{CH}_{2} \mathrm{Cl}_{2}$ ) and recrystallized by $n$ hexane to yield $12 \mathrm{~g}$ (66 \%) of a white crystal: mp $63{ }^{\circ} \mathrm{C} ;{ }^{1} \mathrm{H}-\mathrm{NMR}\left(250 \mathrm{MHz}, \mathrm{CDCl}_{3}, \delta\right.$, ppm ) 0.30 (s, 9H, $\left(\mathrm{CH}_{3}\right)_{3} \mathrm{Si}$ ), 3,76-3.85 (3s, 9H, $\mathrm{OCH}_{3}$ ), 6.81 (s, 1H, $m$ to TMS), 6.947.00 (m, 3Ar-H, 1H o to TMS, 2H o to 4'-methoxy), 7.48 (d, 2Ar-H, $m$ to 4'-methoxy, $J$ $=8.8 \mathrm{~Hz})$.

Synthesis of 4-iodo-2,5,4'-trimethoxy-biphenyl (4b). To a solution of compound 4a ( $10.5 \mathrm{~g}, 33.2 \mathrm{mmol}$ ) in $\mathrm{CH}_{2} \mathrm{Cl}_{2}$ at $-78{ }^{\circ} \mathrm{C}$ was added $1.0 \mathrm{M}$ solution of $\mathrm{ICl}$ in $\mathrm{CH}_{2} \mathrm{Cl}_{2}(40$ 
ml). The reaction mixture was stirred over 2 hrs under nitrogen. $1 \mathrm{M}$ aqueous $\mathrm{Na}_{2} \mathrm{~S}_{2} \mathrm{O}_{5}$ solution was added and stirred over $1 \mathrm{hr}$. The layers were separated, the aqueous layer was washed twice with $\mathrm{CH}_{2} \mathrm{Cl}_{2}$. The combined organic layer was dried over anhydrous $\mathrm{MgSO}_{4}$ and filtered. The solvent was removed in a rotary evaporator, and the crude products was purified by column chromatography (silica gel, $\mathrm{CH}_{2} \mathrm{Cl}_{2}$ ) and recrystallized by $n$-hexane to yield 8.6 g (70 \%) of a white crystal: mp $98{ }^{\circ} \mathrm{C} ;{ }^{1} \mathrm{H}-\mathrm{NMR}(250 \mathrm{MHz}$, $\mathrm{CDCl}_{3}, \delta, \mathrm{ppm}$ ) 3,75-3.85 (3s, 9H, OCH ) 6.79 (s, 1Ar-H, $m$ to I), 6.96 (d, 2Ar-H, o to 4'-methoxy, J = $8.7 \mathrm{~Hz}$ ), 7.34 (s, 1Ar-H, o to I), 7.45 (d, 2Ar-H, $m$ to 4'-methoxy, $J=$ $8.7 \mathrm{~Hz})$.

\section{Synthesis of 4'”-trimethylsilyl-4,2',5'-trimethoxy-[1,1',4',1"-4",1"'-quaterphenyl}

(5a). Compound 4b (2.33 g, $6.29 \mathrm{mmol})$ and 4-trimethylsilyl-biphenyl-4'-boronic acid (1.72 g, $6.36 \mathrm{mmol})$ were dissolved in degassed THF (50 ml). Degassed 2M aqueous $\mathrm{Na}_{2} \mathrm{CO}_{3}(50 \mathrm{ml})$ was added to the solution and then tetrakis(triphenylphosphine) palladium(0) (36 mg, $31 \mu \mathrm{mol}$ ) was added. The mixture was refluxed for 24 hrs with vigorous stirring under nitrogen. Cooled to room temperature, the layers were separated, the aqueous layer was washed twice with ethyl acetate. The combined organic layer was dried over anhydrous $\mathrm{MgSO}_{4}$ and filtered. The solvent was removed in a rotary evaporator, and the crude products was purified by column chromatography (silica gel, $\mathrm{CH}_{2} \mathrm{Cl}_{2}$ ) and then recrystallized by ethanol to yield $2.7 \mathrm{~g}(58 \%)$ of a white crystal : mp $126{ }^{\circ} \mathrm{C} ;{ }^{1} \mathrm{H}-\mathrm{NMR}\left(250 \mathrm{MHz}, \mathrm{CDCl}_{3}, \delta\right.$, ppm ) 0.32 (s, 9H, $\left.\left(\mathrm{CH}_{3}\right)_{3} \mathrm{Si}\right), 3,81-3.87$ (3s, 9H, $\mathrm{OCH}_{3}$ ), 6.98-7.02 (m, 4Ar-H, o to $\mathrm{OCH}_{3}$ ), 7.55 (d, 2Ar-H, o to 4-methoxy, $J=8.7$ ), 7.64-7.68 (m, 8Ar-H). 
Synthesis of 4'"'-iodo-4,2',5'-trimethoxy-[1,1',4',1"-4",1"']-quaterphenyl (5b). To a solution of compound $5 \mathrm{a}(2.7 \mathrm{~g}, 5.7 \mathrm{mmol})$ in $\mathrm{CH}_{2} \mathrm{Cl}_{2}$ at $-78^{\circ} \mathrm{C}$ was added $1.0 \mathrm{M}$ solution of $\mathrm{ICl}$ in $\mathrm{CH}_{2} \mathrm{Cl}_{2}(8 \mathrm{ml})$. The reaction mixture was stirred over $2 \mathrm{hrs}$ under nitrogen. $1 \mathrm{M}$ aqueous $\mathrm{Na}_{2} \mathrm{~S}_{2} \mathrm{O}_{5}$ solution was added and stirred over $1 \mathrm{hr}$. The layers were separated, the aqueous layer was washed twice with $\mathrm{CH}_{2} \mathrm{Cl}_{2}$. The combined organic layer was dried over anhydrous $\mathrm{MgSO}_{4}$ and filtered. The solvent was removed in a rotary evaporator, and the crude products was purified by column chromatography (silica gel, $\mathrm{CH}_{2} \mathrm{Cl}_{2}$ ) and recrystallized by ethanol to yield $2.5 \mathrm{~g}(75 \%)$ of a white crystal: mp 193-198 ${ }^{\circ} \mathrm{C}$; ${ }^{1} \mathrm{H}-\mathrm{NMR}\left(250 \mathrm{MHz}, \mathrm{CDCl}_{3}, \delta\right.$, ppm ) 3,80-3.91 (3s, 9H, OCH ${ }_{3}$ ), 6.98-7.03 (m, 4Ar-H, o to $\mathrm{OCH}_{3}$ ), 7.40 (d, 2Ar-H, $m$ to I, $J=8.4 \mathrm{~Hz}$ ), 7.56 (d, 2Ar-H, $m$ to 4-methoxy, $J=6.9 \mathrm{~Hz}$ ), 7.61-7.71 (m, 4Ar-H, $o$ and $m$ to IPh), 7.79 (d, 2Ar-H, $o$ to I, $J=8.4 \mathrm{~Hz}$ ).

Synthesis of 4,2',5'-trihydroxy-4"'-iodo-[1,1',4',1"-4”,1'”]-quaterphenyl (5c). To a solution of compound $5 \mathbf{b}(0.50 \mathrm{~g}, 0.86 \mathrm{mmol})$ in $\mathrm{CH}_{2} \mathrm{Cl}_{2}$ at $0^{\circ} \mathrm{C}$ was added $1.0 \mathrm{M}$ solution of $\mathrm{BBr}_{3}$ in $\mathrm{CH}_{2} \mathrm{Cl}_{2}(5 \mathrm{ml})$. The reaction mixture was stirred over $2 \mathrm{hrs}$ under nitrogen. Methanol $(10 \mathrm{ml})$ was added and stirred over $1 \mathrm{hr}$. The solvent was removed in a rotary evaporator, and the crude products was purified by column chromatography (silica gel, $\mathrm{CH}_{2} \mathrm{Cl}_{2}$ ) followed by ethyl acetate) to yield $0.42 \mathrm{~g}(90 \%)$ of a brownish solid: $\mathrm{T}_{\mathrm{dec}}>280{ }^{\circ} \mathrm{C} ;{ }^{1} \mathrm{H}-\mathrm{NMR}$ (250 MHz, DMSO, $\delta$, ppm) 6.76-6.85 (m, 4Ar-H, o to OH), 7.36 (d, 2Ar-H, $m$ to I, $J=8.6 \mathrm{~Hz}$ ), 7.52 (d, 2Ar-H, $m$ to 4-hydroxy, $J=6.8 \mathrm{~Hz}$ ), 7.61-7.70 (m, 4Ar-H, $m$ and $o$ to IPh), 7.82 (d, 2Ar-H, $o$ to I, $J=8.4 \mathrm{~Hz}$ ), 8.81, 8.93, $9.39(3 \mathrm{~s}, 3 \mathrm{H}, \mathrm{OH})$. 
Synthesis of compound $5 \mathbf{d}$ and $\mathbf{6 d}$. Compound $5 \mathbf{d}$ and $\mathbf{6 d}$ were synthesized by using the same procedure. A representative example is described for $\mathbf{6 d}$. Compound 5c (1.9 g, $3.5 \mathrm{mmol}), \mathrm{R}_{2} \mathrm{OTs}(7.4 \mathrm{~g}, 11 \mathrm{mmol})$ and $\mathrm{K}_{2} \mathrm{CO}_{3}(3.1 \mathrm{~g}, 22 \mathrm{mmol})$ were dissolved in $\mathrm{CH}_{3} \mathrm{CN}$ (70 ml). The reaction mixture was refluxed 72 hrs under nitrogen. Cooled to room temperature, the water $(100 \mathrm{ml})$ was added and the aqueous layer was washed twice with ethyl acetate. The combined organic layer was dried over anhydrous $\mathrm{MgSO}_{4}$ and filtered. The solvent was removed in a rotary evaporator. The crude products was purified by column chromatography (silica gel, ethyl acetate followed by THF to yield $6.0 \mathrm{~g}(86 \%)$ of a colorless oil; ${ }^{1} \mathrm{H}-\mathrm{NMR}\left(250 \mathrm{MHz}, \mathrm{CDCl}_{3}, \delta\right.$, ppm) 2.13-2.25 (m, 9H, $\left.\mathrm{C}\left(\mathrm{CH}_{2}\right)_{3} \mathrm{H}\right), 3.30-3.57$ (m, 120H, $\left.\mathrm{OCH}_{2}\right), 4.00$ (m, 6H, $\left.\mathrm{CH}_{2} \mathrm{OPh}\right), 6.92-6.99(\mathrm{~m}, 4 \mathrm{Ar}-\mathrm{H}$, $o$ to $\mathrm{OCH}_{2}$ ), 7.40 (d, 2Ar-H, $o$ to I, $J=8.4 \mathrm{~Hz}$ ), 7.48 (d, $2 \mathrm{Ar}-\mathrm{H}, m$ to $\mathrm{OCH}_{2}, J=8.6 \mathrm{~Hz}$ ), 7.58-7.62 (m, 4Ar-H), 7.78 (d, 2H, $m$ to I, $J=8.4 \mathrm{~Hz}$ ).

Compound 5d: ${ }^{1} \mathrm{H}-\mathrm{NMR}$ (250 MHz, $\mathrm{CDCl}_{3}, \delta$, ppm), 2.33-2.37 (m, 3H, $\mathrm{C}\left(\mathrm{CH}_{2}\right)_{3} \mathrm{H}$ ), 3.31-3.66 (m, 54H, $\left.\mathrm{OCH}_{2}\right), 4.02\left(\mathrm{~m}, 6 \mathrm{H}, \mathrm{CH}_{2} \mathrm{OPh}\right), 6.92-6.99\left(\mathrm{~m}, 4 \mathrm{Ar}-\mathrm{H}, \mathrm{o}\right.$ to $\left.\mathrm{OCH}_{2}\right)$, 7.39 (d, 2Ar-H, o to I, $J=8.4 \mathrm{~Hz}$ ), 7.47 (d, 2Ar-H, $m$ to $\mathrm{OCH}_{2}, J=8.5 \mathrm{~Hz}$ ), 7.56-7.65 (m, 4Ar-H), 7.78 (d, 2H, $m$ to I, $J=8.4 \mathrm{~Hz}$ ).

Synthesis of compound 7a and 8a. Compound 7a and 8a were synthesized by using the same procedure. A representative example is described for $\mathbf{8 a}$. Compound $\mathbf{6 d}$ (1.0 g, $0.51 \mathrm{mmol}$ ) and 4-trimethyl silyl-biphenyl-4'-boronic acid (140 mg, $0.52 \mathrm{mmol}$ ) were dissolved in degassed THF (50 ml). Degassed 2M aqueous $\mathrm{Na}_{2} \mathrm{CO}_{3}(50 \mathrm{ml})$ was added to the solution and then tetrakis(triphenylphosphine)palladium(0) (2.9 mg, $2.5 \mu \mathrm{mol}$ ) was added. The mixture was refluxed for 24 hrs with vigorous stirring under nitrogen. 
Cooled to room temperature, the layers were separated, the aqueous layer was washed twice with ethyl acetate. The combined organic layer was dried over anhydrous $\mathrm{MgSO}_{4}$ and filtered. The solvent was removed in a rotary evaporator, and the crude products was purified by column chromatography (silica gel, ethyl acetate followed by THF) to yield 0.66 g (63 \%) of a light yellow oil; ${ }^{1} \mathrm{H}-\mathrm{NMR}\left(250 \mathrm{MHz}, \mathrm{CDCl}_{3}, \delta\right.$, ppm ) 0.32 (s, 9H, $\left.\left(\mathrm{CH}_{3}\right)_{3} \mathrm{Si}\right), 2.13-2.25\left(\mathrm{~m}, 9 \mathrm{H}, \mathrm{C}\left(\mathrm{CH}_{2}\right)_{3} \mathrm{H}\right), 3.30-3.57$ (m, 120H, OCH $), 4.00(\mathrm{~m}, 6 \mathrm{H}$, $\mathrm{CH}_{2} \mathrm{OPh}$ ), 6.93-7.02 (m, 4Ar-H, o to $\mathrm{OCH}_{2}$ ), 7.50 (d, 2Ar-H, $m$ to $\mathrm{OCH}_{2}, J=8.6 \mathrm{~Hz}$ ), 7.62-7.76 (m, 16Ar-H).

Compound 7a: ${ }^{1} \mathrm{H}-\mathrm{NMR}\left(250 \mathrm{MHz}, \mathrm{CDCl}_{3}, \delta\right.$, ppm ) 0.32 (s, 9H, $\left.\left(\mathrm{CH}_{3}\right)_{3} \mathrm{Si}\right), 2.35-2.49$ (m, 3H, C( $\left.\left(\mathrm{CH}_{2}\right)_{3} \mathrm{H}\right), 3.32-3.57$ (m, 54H, $\left.\mathrm{OCH}_{2}\right), 4.03$ (m, 6H, $\left.\mathrm{CH}_{2} \mathrm{OPh}\right), 6.93-6.99$ (m, 4Ar-H, $o$ to $\mathrm{OCH}_{2}$ ), 7.49 (d, 2Ar-H, $m$ to $\mathrm{OCH}_{2}, J=8.6 \mathrm{~Hz}$ ), 7.64-7.76 (m, 16Ar-H).

Synthesis of compound $\mathbf{7 b}$ and $\mathbf{8 b}$. Compound $\mathbf{7 b}$ and $\mathbf{8 b}$ were synthesized by using the same procedure. A representative example is described for $\mathbf{8 b}$. To a solution of compound $8 \mathrm{a}$ ( $0.3 \mathrm{~g}, 0.135 \mathrm{mmol})$ in $\mathrm{CH}_{2} \mathrm{Cl}_{2}$ at $-78{ }^{\circ} \mathrm{C}$ was dropped $1.0 \mathrm{M}$ solution of $\mathrm{ICl}$ in $\mathrm{CH}_{2} \mathrm{Cl}_{2}(30 \mathrm{ml})$. The reaction mixture was stirred over $2 \mathrm{hrs}$ under nitrogen. $1 \mathrm{M}$ aqueous $\mathrm{Na}_{2} \mathrm{~S}_{2} \mathrm{O}_{5}$ solution was added and stirred over $1 \mathrm{hr}$. The layers were separated, the aqueous layer was washed twice with $\mathrm{CH}_{2} \mathrm{Cl}_{2}$. The combined organic layer was dried over anhydrous $\mathrm{MgSO}_{4}$ and filtered. The solvent was removed in a rotary evaporator, and the crude products was purified by column chromatography (silica gel, ethyl acetate followed by THF) to yield $0.27 \mathrm{~g}$ (93 \%) of a light yellow oil; ${ }^{1} \mathrm{H}-\mathrm{NMR}$ (250 MHz, $\left.\mathrm{CDCl}_{3}, \delta, \mathrm{ppm}\right)$ 2.13-2.25 (m, 9H, C( $\left.\mathrm{CH}_{2}\right)_{3} H$ ), 3.36-3.62 (m, 120H, $\mathrm{OCH}_{2}$ ), 3.98 (m, 6H, $\mathrm{CH}_{2} \mathrm{OPh}$ ), 6.93-7.01 (m, 4Ar-H, o to $\mathrm{OCH}_{2}$ ), 7.40 (d, 2Ar-H, o to TMS, $J$ 
$=8.4 \mathrm{~Hz}), 7.50\left(\mathrm{~d}, 2 \mathrm{Ar}-\mathrm{H}, m\right.$ to $\left.\mathrm{OCH}_{2}, J=8.6 \mathrm{~Hz}\right), 7.64-7.81(\mathrm{~m}, 16 \mathrm{Ar}-\mathrm{H})$.

Compound 7b: ${ }^{1} \mathrm{H}-\mathrm{NMR}$ (250 MHz, $\mathrm{CDCl}_{3}, \delta$, ppm) 2.37-2.39 (m, 3H, $\mathrm{C}\left(\mathrm{CH}_{2}\right)_{3} \mathrm{H}$ ), 3.31-3.67 (m, 54H, $\mathrm{OCH}_{2}$ ), 4.05 (m, 6H, $\left.\mathrm{CH}_{2} \mathrm{OPh}\right), 6.93-7.03$ (m, 4Ar-H, o to $\mathrm{OCH}_{2}$ ), 7.40 (d, 2Ar-H, o to TMS, J = 8.4 Hz), 7.49 (d, 2Ar-H, $m$ to $\left.\mathrm{OCH}_{2}, J=8.6 \mathrm{~Hz}\right), 7.50-$ $7.81(\mathrm{~m}, 14 \mathrm{Ar}-\mathrm{H})$.

Synthesis of compound 1 and 2. Compound 1 and 2 were synthesized by using the same procedure. A representative example is described for 2.Compound $\mathbf{8 b}(0.27 \mathrm{~g}$, $0.126 \mathrm{mmol}$ ) and 4-phenyl-phenyl boronic acid (32.4 $\mathrm{mg}, 0.164 \mathrm{mmol}$ ) were dissolved in degassed THF (30 ml). Degassed $2 \mathrm{M}$ aqueous $\mathrm{Na}_{2} \mathrm{CO}_{3}(30 \mathrm{ml})$ was added to the solution and then tetrakis (triphenylphosphine)palladium(0) (1 mg, $0.86 \mu \mathrm{mol}$ ) was added. The mixture was refluxed for 24 hrs with vigorous stirring under nitrogen. Cooled to room temperature, the layers were separated, the aqueous layer was washed twice with ethyl acetate. The combined organic layer was dried over anhydrous $\mathrm{MgSO}_{4}$ and filtered. The solvent was removed in a rotary evaporator, and the crude products was purified by column chromatography (silica gel, ethyl acetate followed by THF) and precipitated by diethyl ether and n-hexane to yield $0.20 \mathrm{~g}$ (74\%) of a waxy solid: mp 76.6 ${ }^{\circ} \mathrm{C}$; GPC $\overline{\mathrm{M}}_{\mathrm{w}} / \overline{\mathrm{M}}_{\mathrm{n}}=1.03,{ }^{1} \mathrm{H}-\mathrm{NMR}\left(250 \mathrm{MHz}, \mathrm{CDCl}_{3}, \delta, \mathrm{ppm}\right)$ 2.04-2.27 (m, 9H, $\left.\mathrm{C}\left(\mathrm{CH}_{2}\right)_{3} \mathrm{H}\right), 3.30-3.56\left(\mathrm{~m}, 120 \mathrm{H}, \mathrm{OCH}_{2}\right), 4.00$ (m, 6H, $\left.\mathrm{CH}_{2} \mathrm{OPh}\right), 6.94-7.03$ (m, 4Ar-H, $o$ to $\mathrm{OCH}_{2}$ ), 7.37-7.52 (m, 5Ar-H), 7.65-7.77 (m, 22Ar-H); ${ }^{13} \mathrm{C}-\mathrm{NMR}\left(125 \mathrm{MHz}, \mathrm{CDCl}_{3}\right.$, $\delta$, ppm) 58.9, 66.2, 67.2, 67.5, 69.3, 69.7, 70.4, 71.8, 113.9, 115.3, 115.6, 126.4, 126.9, 127.3, 128.7, 129.6, 130.0, 130.4, 137.6, 138.9, 139.6, 139.8, 140.1, 140.6, 150.1, 158.2; MALDI-TOF-MS m/z (M+) 2148.5, Calcd 2148.6; Anal. Calcd for $\mathrm{C}_{120} \mathrm{H}_{178} \mathrm{O}_{33}$ : 
C, 67.03; H, 8.02. Found C, 67.06 ; H, 8.44.

Compound 1: mp $135.3{ }^{\circ} \mathrm{C}$ GPC; $\overline{\mathrm{M}}_{\mathrm{w}} / \overline{\mathrm{M}}_{\mathrm{n}}=1.04,{ }^{1} \mathrm{H}-\mathrm{NMR}\left(250 \mathrm{MHz}, \mathrm{CDCl}_{3}, \delta\right.$, ppm) 2.38-2.52 (m, 3H, C( $\left.\left(\mathrm{CH}_{2}\right)_{3} \mathrm{H}\right), 3.31-3.68\left(\mathrm{~m}, 120 \mathrm{H}, \mathrm{OCH}_{2}\right), 4.00(\mathrm{~m}, 6 \mathrm{H}$, $\mathrm{CH}_{2} \mathrm{OPh}$ ), 6.94-7.06 (m, 4Ar-H, o to $\mathrm{OCH}_{2}$ ), 7.45-7.48 (m, 5Ar-H), 7.66-7.78 (m, 22Ar$\mathrm{H}) ;{ }^{130} \mathrm{C}-\mathrm{NMR}\left(125 \mathrm{MHz}, \mathrm{CDCl}_{3}, \delta\right.$, ppm) 59.0, 66.1, 67.4, 67.6, 69.4, 70.4, 71.8, 113.9, 115.7, 115.8, 126.3, 127.0, 127.4, 128.8, 129.7, 130.0, 130.5, 137.6, 138.9, 139.5, 139.8, 140.1, 140.6, 150.2, 158.2; MALDI-TOF-MS m/z (M+) 1270.7, Calcd 1270.7; Anal. Calcd for $\mathrm{C}_{78} \mathrm{H}_{94} \mathrm{O}_{15}$ : C,73.68; H, 7.45. Found C,73.69 ; H,7.41

Preparation of Capsules. The compounds were first dissolved in THF and mixed with deionized water (prefiltered with a $0.45 \mu \mathrm{m}$ pore PTFE membrane filter) at the volume ratio of 1 to 10 . Then the solution was diluted with the THF/water mixture of the same composition to desired concentrations and filtered with a $0.45 \mu \mathrm{m}$ pore membrane filter. 

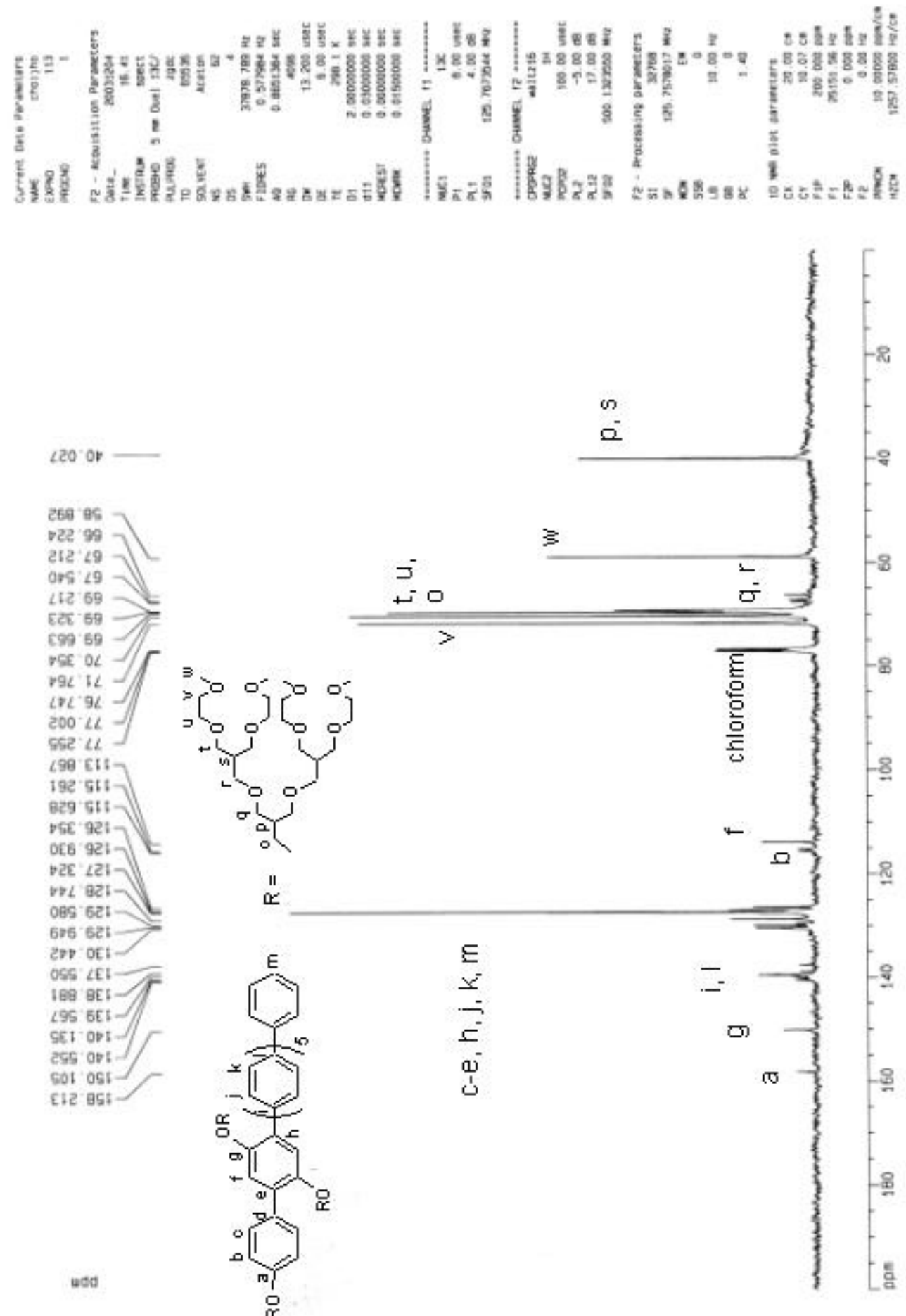

Figure S1. ${ }^{13} \mathrm{C}$ NMR of molecule 2 . 


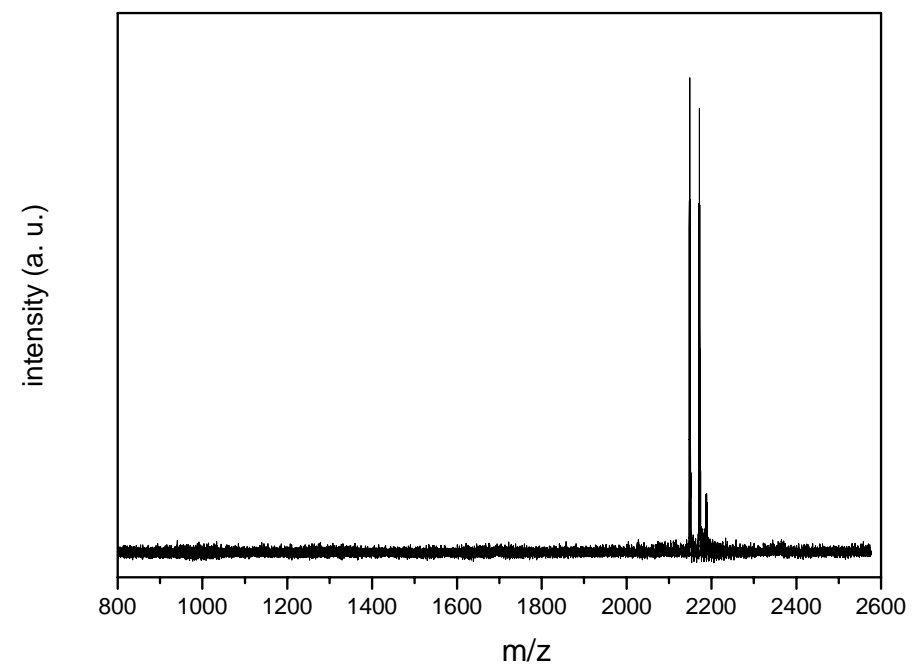

Figure S2. MALDI-TOF spectrum of molecule $\mathbf{2}$

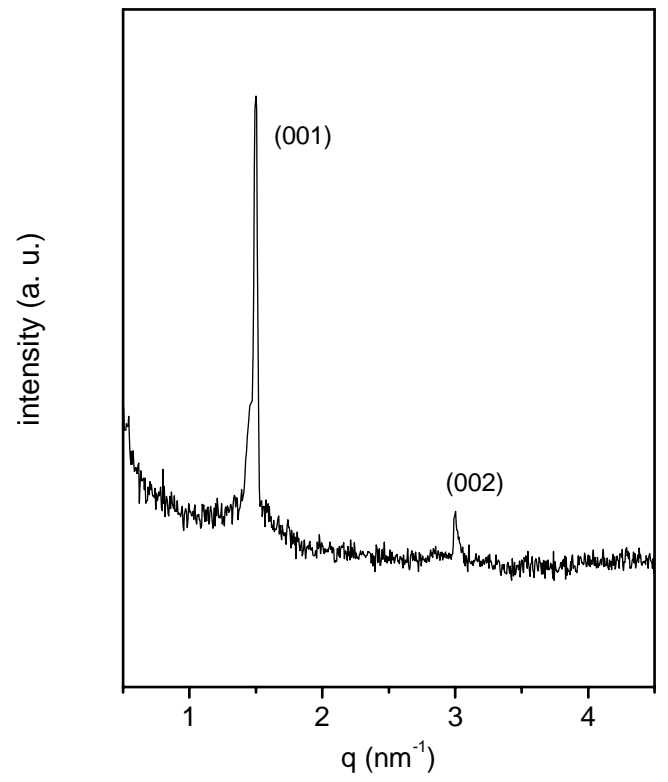

Figure S3. SAXS of molecule 1. 